\title{
PRODUCTION AND PARTIAL CHARACTERIZATION OF POLYGALACTURONASES PRODUCED BY THERMOPHILIC MONASCUS SP N8 AND BY THERMOTOLERANT ASPERGILLUS SP N12 ON SOLID-STATE FERMENTATION
}

\author{
Paula Mendes de Freitas; Natalia Martin; Dênis Silva; Roberto da Silva; Eleni Gomes* \\ Laboratório de Bioquímica e Microbiologia Aplicada, Instituto de Biociências, Letras e Ciências Exatas, Universidade Estadual \\ Paulista, São José do Rio Preto, SP, Brasil
}

Submitted: November 26, 2004; Returned to authors for corrections: April 27, 2005; Approved: May 08, 2006

\begin{abstract}
Polygalacturonases production by newly isolated Monascus sp N8 and Aspergillus sp N12 strains was carried out in solid-state fermentation using mixtures of wheat bran, sugar cane bagasse and orange bagasse as carbon sources. The maximal activity values of exo-polygalacturonases (exo-Pg) from Monascus sp and Aspergillus sp were obtained using wheat bran/sugar cane bagasse/orange bagasse mixture $(6.6 \mathrm{U} / \mathrm{mL})$ and wheat bran/orange bagasse mixture $(10 \mathrm{U} / \mathrm{mL})$, respectively. Enzyme production by both strains was higher at $45^{\circ} \mathrm{C}$ after $72 \mathrm{~h}$ and $1.6 \mathrm{U} / \mathrm{mL}$ at $50^{\circ} \mathrm{C}$ after $120 \mathrm{~h}$. Endo-polygalacturonase (endo-Pg) production was higher in wheat bran/orange bagasse mixture and was not affected by temperature of incubation for both fungi. EndoPg production by Monascus was $1.8 \mathrm{U} / \mathrm{mL}$ at $45^{\circ} \mathrm{C}$ and $50^{\circ} \mathrm{C}$, after 72 . Similar values were obtained in Aspergillus sp culture, $1.9 \mathrm{U} / \mathrm{mL}$ at $45^{\circ} \mathrm{C}$ and $1.8 \mathrm{U} / \mathrm{mL}$ at $50^{\circ} \mathrm{C}$.Exo-Pg from both strains showed optimum activity at $\mathrm{pH} 5.5$. Maximal activity was determined at $60^{\circ} \mathrm{C}$ for enzyme from Monascus sp and $50^{\circ} \mathrm{C}$ for that produced by Aspergillus sp. Exo-Pg from Monascus $\mathrm{sp}$ was stable at $\mathrm{pH}$ range 4.5-6.0 whereas that from Aspergillus $\mathrm{sp}$ enzyme was stable at $\mathrm{pH}$ 4.0. Both enzymes showed stability when incubated at $50^{\circ} \mathrm{C}$ for $1 \mathrm{~h}$, in absence of substrate.
\end{abstract}

Key words: Monascus sp, Aspergillus sp, thermophilic, polygalacturonase, solid-state fermentation

\section{INTRODUCTION}

The increasing energy demand has been focused worldwide attention on the utilization of renewable resources, particularly agricultural and industrial wastes. The agricultural and agro-industrial wastes, such as wheat bran, rice husk, corn straw, corn cob, fruit peels, paper industry wastes and orange and sugarcane bagasses have high organic matter content and their disposal arise both economic and environmental problems. On the other hand, their major components as cellulose, starch, lignin, xylan and pectin can be used by several microorganisms as carbon and energy sources producing enzymes and other products with high commercial value $(1,3)$.

The pectin is degraded by de-esterifiyng enzymes (pectinesterases), depolymerizing enzymes (hydrolases and liases) and protopectinases. Polygalacturonases catalyze the hydrolytic cleavage of the $\alpha-1,4$-glycosidic bonds between galacturonic acid units by endo and exo action (15). Pectinases are extensively used in the industrial clarification of wine and fruit juices, maceration of fruits and vegetable tissues and coffee and tea processing. In addition, are involved in the retting and degumming of fiber crops, such as jute, flax and ramie $(3,9)$.

Although a number of polygalacturonases have been studied there are few reports about the production of polygalacturonases by thermophilic fungi $(7,11,16)$. The present study was carried out on the production of polygalacturonases from newly isolated thermophilic Monascus sp and Aspergillus sp in solid-state fermentation and partial characterization of the enzymes.

*Corresponding Author. Mailing address: Laboratório de Bioquímica e Microbiologia Aplicada, Instituto de Biociências, Letras e Ciências Exatas, IBILCE, UNESP. 15054-000, São José do Rio Preto, SP, Brasil. Tel.: (+5517) 3221-2393, Fax: (+5517) 3221-2390. E-mail: eleni@ibilce.unesp.br 


\section{MATERIALS AND METHODS}

\section{Microorganisms}

The Monascus sp N8 and Aspergillus sp N12 strains used in this study were recently isolated from compost samples, at Constroeste Construtora e Participações Ltda in São José do Rio Preto, São Paulo state, Brazil. The strains were sub-cultured on to agar slants (pH 5.5), containing: $1 \%$ citrus pectin; $0.2 \%$ meat peptone; $0.2 \%$ yeast extract; $0.2 \%\left(\mathrm{NH}_{4}\right)_{2} \mathrm{SO}_{4} .7 \mathrm{H}_{2} \mathrm{O} ; 0.1 \%$ $\mathrm{MgSO}_{4} .7 \mathrm{H}_{2} \mathrm{O} ; 0.5 \%$ element trace solution $\left(2.2 \mathrm{~g} \mathrm{ZnSO}_{4} .7 \mathrm{H}_{2} \mathrm{O}\right.$; $1.1 \mathrm{~g} \mathrm{H}_{3} \mathrm{BO}_{3} ; 0.5 \mathrm{~g} \mathrm{MnCl}_{2} .4 \mathrm{H}_{2} \mathrm{O} ; 0.5 \mathrm{~g} \mathrm{FeSO}_{4} .7 \mathrm{H}_{2} \mathrm{O} ; 0.16 \mathrm{~g}$ $\mathrm{CoCl}_{2} .5 \mathrm{H}_{2} \mathrm{O} ; 0.16 \mathrm{~g} \mathrm{CuSO}_{4} .5 \mathrm{H}_{2} \mathrm{O} ; 0.11 \mathrm{~g}\left(\mathrm{NH}_{4}\right)_{6} \mathrm{Mo}_{7} \mathrm{O}_{24} .4 \mathrm{H}_{2} \mathrm{O} ; 5 \mathrm{~g}$ EDTA) and 3\% agar.

\section{Enzyme production in solid-state fermentation (SSF)}

The solid substrates were prepared as follows:

(a) Orange bagasse: The pellet of orange bagasse (pressed mixture of pulp and peel) was provided by Citrovita Agro-Industrial Ltda, Catanduva, SP, Brazil. Chemical analysis revealed that the dry material was composed of $11.8 \%$ fibre, $6.4 \%$ protein, $6.3 \%$ nitrogen, $6.7 \%$ ash, $19 \%$ total sugar (9\% reducing sugar) and $0.1 \%$ pectin. The material was ground and particles sieved by a Bender USS 230 strainer and dried at $80^{\circ} \mathrm{C}$.

(b) Sugar cane bagasse: The sugar cane bagasse was provided by Usina de Açúcar e Álcool São Domingos, Catanduva, SP, Brazil. Chemical analysis revealed that the dry material was composed of $75 \%$ fibre, $5 \%$ nitrogen, $3.4 \%$ ash and $10.3 \%$ total sugar (3.5\% reducing sugar). The material was washed in tap water and the same procedure described above was followed.

(c) Wheat bran: This material was obtained commercially, dried and used untreated. Chemical analysis revealed that the dry material was composed of $8.1 \%$ fiber, $7.5 \%$ nitrogen, $4.6 \%$ ash and $16.7 \%$ total sugar (5.2\% reducing sugar).

The substrate mixtures was prepared in proportions of (w/ w): 1-Wheat bran; 2-wheat bran / sugar cane bagasse (1:1); 3wheat bran / orange bagasse (1:1); 4-wheat bran / sugar cane bagasse / orange bagasse (1:1:1).

Solid-state fermentation (SSF) by Monascus sp N8 was carried out using $5 \mathrm{~g}$ of sterilized substrate inoculated with micelial suspension (approximately $3.0 \mathrm{mg}$ dry micelial mass per g dry substrate), which was obtained from a 3-day agar slant culture. After inoculation, $10 \mathrm{~mL}$ of nutrient solution, composed of $0.1 \%\left(\mathrm{NH}_{4}\right)_{2} \mathrm{SO}_{4}$ and $0.1 \% \mathrm{MgSO}_{4} .7 \mathrm{H}_{2} \mathrm{O}$ were added. The final moisture content of the medium was $70 \%$. SSF by Aspergillus sp N12 was carried out in the same way except and the inoculum was approx. $10^{7}$ spores per $\mathrm{g}$ dry substrate.

Cultures were incubated at $45^{\circ} \mathrm{C}$ and $50^{\circ} \mathrm{C}$ for 6 days. After $48 \mathrm{~h}$ and at intervals of $24 \mathrm{~h}, 40 \mathrm{~mL}$ distilled water were added to the cultures, stirred for $40 \mathrm{~min}$, filtered under vacuum and centrifuged. The supernatant was used as enzyme solution. The shown results are the mean of 3 experiments.

\section{Enzyme activity measurements}

Exo-polygalacturonase (Exo-Pg) activity was determined by measuring the release of reducing groups from citrus pectin by the dinitrosalicylic acid method (12). The reaction mixture containing $0.8 \mathrm{~mL} 1 \%$ citric pectin $67 \%$ methoxylated (CPKelco) in $0.2 \mathrm{M}$ acetate buffer, $\mathrm{pH} 5.5$ and $0.2 \mathrm{~mL}$ of enzyme solution, was incubated at $50^{\circ} \mathrm{C}$ for $10 \mathrm{~min}$. A control containing water instead of enzyme solution was performed. One activity unit (U) was defined as the amount of enzyme which releases $1 \mu \mathrm{mol}$ of galacturonic acid in one minute.

Endo-polygalacturonase (endo-PG) was measured viscosimetrically by adding $2 \mathrm{~mL}$ of crude enzyme to $6 \mathrm{~mL}$ of citrate- $\mathrm{NaOH}$ buffer ( $\mathrm{pH} 5.5$ ) containing $3 \%$ of $67 \%$ methoxylated citric pectin. The reaction mixture was incubated at $50^{\circ} \mathrm{C}$ for 15 minutes, after which its viscosity was determined with a Basic viscosimeter (Fungilab). The blank contained thermally-inactivated crude enzyme. One unit of enzyme activity (U) was defined as the amount of enzyme that reduced the initial viscosity by $50 \%$ per minute.

\section{Enzyme characterization}

Apparent optimun $\mathrm{pH}$ and temperature for enzyme activity: The optimum $\mathrm{pH}$ was determined by measuring activity at $50^{\circ} \mathrm{C}$ for enzyme from Aspergillus sp and $60^{\circ} \mathrm{C}$ for enzyme from Monascus sp, using as buffers sodium acetate ( $\mathrm{pH}$ 3.0-5.0), citrate-phosphate ( $\mathrm{pH}$ 5.0-7.0), tris- $\mathrm{HCl}(\mathrm{pH} 7.0-8.5)$ and glycine$\mathrm{NaOH}(\mathrm{pH} 8.5-11.0)$. The optimum temperature was assayed by incubating each reaction mixture at $45-85^{\circ} \mathrm{C}$.

Thermostability: a thin layer of mineral oil prevented evaporation of the crude enzyme solution which was incubated at various temperatures $\left(10-90^{\circ} \mathrm{C}\right)$ for $1 \mathrm{~h}$ at $\mathrm{pH}$ 5.5. An aliquot was withdrawn and placed on ice before assaying for residual enzyme activity at the optimum $\mathrm{pH}$ and temperature.

pH stability: Crude enzyme was dispersed (1:1) in $0.1 \mathrm{M}$ buffer solutions $\mathrm{pH}$ 3.0-5.5 (sodium acetate), $\mathrm{pH}$ 5.5-7.0 (citratephosphate), pH 7.0-8.5 (tris-HCl) and pH 8.5-11.0 (glycine- $\mathrm{NaOH}$ ) and maintained at $27^{\circ} \mathrm{C}$ for $24 \mathrm{~h}$. An aliquot was used to determine the remaining activity at the optimum $\mathrm{pH}$ and temperature.

\section{RESULTS AND DISCUSSION}

\section{Polygalacturonases production in SSF}

Thermophilic Monascus sp and thermotolerant Aspergillus $\mathrm{sp}$, when cultivated in medium with wheat bran (W); wheat bran and sugar cane bagasse (W/C); wheat bran and orange bagasse (W/O); wheat bran, sugar cane bagasse and orange bagasse $(\mathrm{W} / \mathrm{C} / \mathrm{O})$, produced exo-Poligalacturonase (exo-Pg) and endo- Poligalacturonase (endo-Pg) (Figs. 1, 2).

For both strains, the higher exo-Pg production was observed at $45^{\circ} \mathrm{C}$ than at $50^{\circ} \mathrm{C}$. The growth of the fungi at $50^{\circ} \mathrm{C}$ was negligible with possible hyphae death and low enzyme production (Fig. 1). It was also observed that the enzymatic 
production was low for both strains when solely wheat bran was used as carbon source. Exo-Pg production using mixture of wheat bran and orange bagasse at $45^{\circ} \mathrm{C}$ peaked after $96 \mathrm{~h}$ of fermentation with $10 \mathrm{U} / \mathrm{mL}$ and $5 \mathrm{U} / \mathrm{mL}$ in culture media of Aspergillus sp and Monascus sp, respectively (Figs. 1A and C). The highest exo-Pg production by Monascus $\mathrm{sp}(6.6 \mathrm{U} / \mathrm{mL})$ was observed after $96 \mathrm{~h}$ growing in mixture of the wheat bran, sugar cane and orange bagasse (Fig. 1A). The consistence and size of particles in media composed only of wheat bran could with-stand a change in the packing of the substrate particle

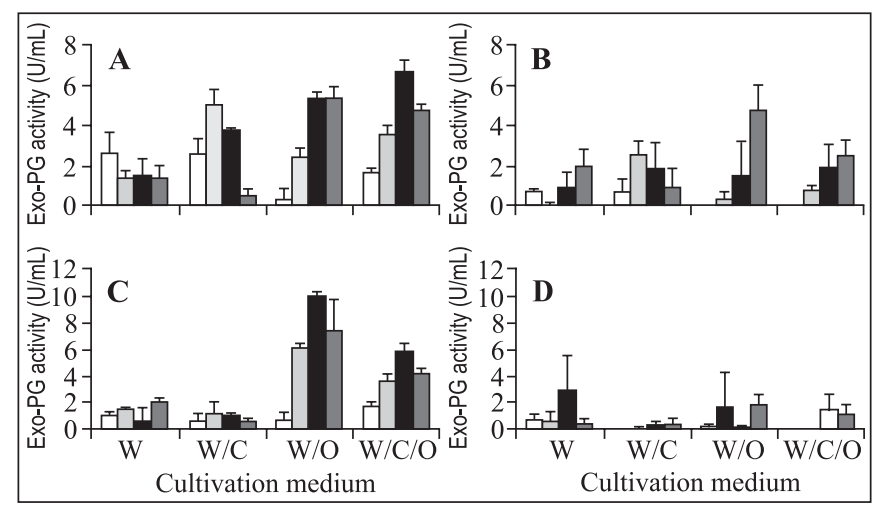

Figure 1. Production of exo-polygalacturonase by Monascus sp N8 and Aspergillus sp N12 strains in solid-state fermentation. $\mathrm{A}, \mathrm{B}=$ Monascus $\mathrm{sp} ; \mathrm{C}, \mathrm{D}=$ Aspergillus $\mathrm{sp} ; \mathrm{A}, \mathrm{C}$ $=45^{\circ} \mathrm{C} ; \mathrm{B}, \mathrm{D}=50^{\circ} \mathrm{C}$. SSF was carried out on various substrates, as indicated in figure, and different time intervals. $\square=48 \mathrm{~h}$, $=72 \mathrm{~h}, \boldsymbol{\square}=96 \mathrm{~h}, \square=120 \mathrm{~h}$.

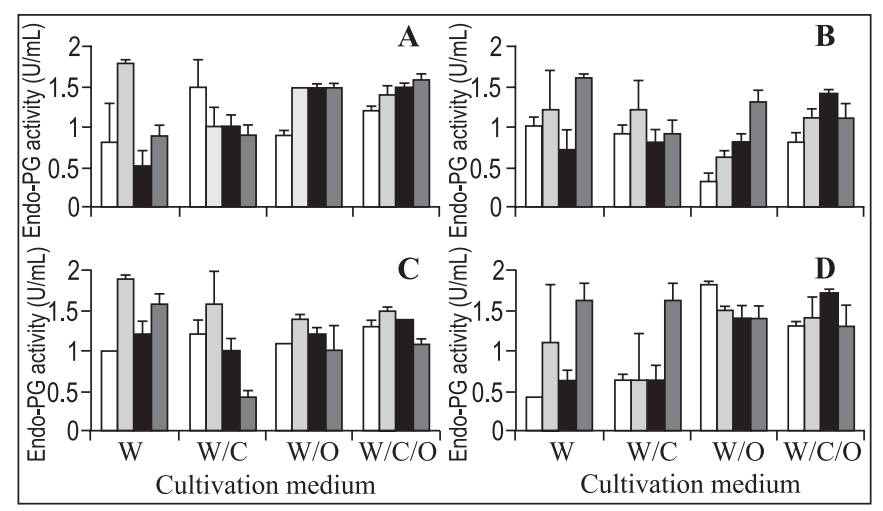

Figure 2. Production of endo-polygalacturonase by Monascus sp N8 and Aspergillus sp N12 strains by solid-state fermentation. $\mathrm{A}, \mathrm{B}=$ Monascus $\mathrm{sp} ; \mathrm{C}, \mathrm{D}=$ Aspergillus $\mathrm{sp} ; \mathrm{A}, \mathrm{C}$ $=45^{\circ} \mathrm{C} ; \mathrm{B}, \mathrm{D}=50^{\circ} \mathrm{C}$. SSF was carried out on various substrates, as indicated in figure, and different time intervals. $\square=48 \mathrm{~h}, \square$ $=72 \mathrm{~h}, \boldsymbol{\square}=96 \mathrm{~h}, \square=120 \mathrm{~h}$. during the fermentation, since the bed remained static (nonmixed system), playing a role in affecting heat and mass transfer within the system (13). These results are in agreement with the literature, since is known that addition of fibrous material to solid fermentation medium, increase the inter-particle spacing possibly increasing the aeration and nutrient and enzyme diffusion $(14,16)$. However, for Aspergillus sp, the presence of sugar cane bagasse reduced of enzyme production (Fig. 1C).

The effect of different carbon sources on pectinase synthesis by fungi in SSF have been studied and it is generally agreed that the optimum medium for the enhanced production of extracellular pectinase is that containing pectic materials as an inducer $(5,8,17)$. According to this, the present results corroborate that the culture medium with high levels of pectin, such as orange bagasse, raised the highest exo-Pg activity (11).

Data of Fig. 2 showed that, on the contrary of obtained for exo-Pg, the production of endo-Pg was not significantly affected by temperature and composition of the culture medium (Figs. 2B and D). The enzyme production by Monascus sp at $45^{\circ} \mathrm{C}$ was $1.8 \mathrm{U} / \mathrm{mL}$ after $72 \mathrm{~h}$, when wheat bran was the carbon source (Fig. $2 \mathrm{~A}$ ). At $50^{\circ} \mathrm{C}$, the maximum activity value was $1.6 \mathrm{U} / \mathrm{mL}$ in $20 \mathrm{~h}$ in the same conditions (Fig. 2B). In Aspergillus sp culture, at $45^{\circ} \mathrm{C}$, activity of $1.9 \mathrm{U} / \mathrm{mL}$ was detected after $72 \mathrm{~h}$ with wheat bran as substrate (Fig. 2C). The maximum activity obtained in fermentation at $50^{\circ} \mathrm{C}$ was $1.8 \mathrm{U} / \mathrm{mL}$ when a mixture of wheat bran and orange bagasse was the substrate (Fig. 2D).

The present results indicate that the agro-industrial wastes such as wheat bran, orange bagasse and sugar cane bagasse are suitable for polygalacturonase production by newly isolated Monascus sp N8 and Aspergillus sp N12 at $45^{\circ} \mathrm{C}$ in SSF.

The $\mathrm{pH}$ culture medium didn't show large variation in any medium (Fig. 3). In all of them the $\mathrm{pH}$ increased a little after $96 \mathrm{~h}$ of cultivation.

\section{Enzyme characterization}

For characterization of exo-Pg from Monascus sp N8 was used the enzyme obtained after $96 \mathrm{~h}$ of fermentation at $45^{\circ} \mathrm{C}$, in mixture of wheat bran, orange bagasse and sugar cane bagasse as substrate. For exo-Pg form Aspergillus sp N12 it was used the enzyme obtained in the same incubation conditions but using mixture of wheat bran and orange bagasse.

The maximal activity was observed at $\mathrm{pH} 5.5$ for exo-Pg from both strains (Fig. 4). The optimum pH found for the exo-Pg is comparable to those from other fungal strains (6). Exo-Pg from Monascus sp was stable at $\mathrm{pH}$ 4.5-6.0 while that from Aspergillus sp, was stable at pH 4.0 (Figs. 6A and B). The acid tolerance property of these enzymes is a great advantage in fruit and vegetable processing applications, since most fruit and vegetable tissues and juices have acidic $\mathrm{pH}$.

Exo-Pg from Monascus sp and Aspergillus sp exhibited maximal activity at $60^{\circ} \mathrm{C}$ and $50^{\circ} \mathrm{C}$, respectively (Fig. 5). Both enzymes showed stability at temperatures up to $50^{\circ} \mathrm{C}$ (Fig. 7) 


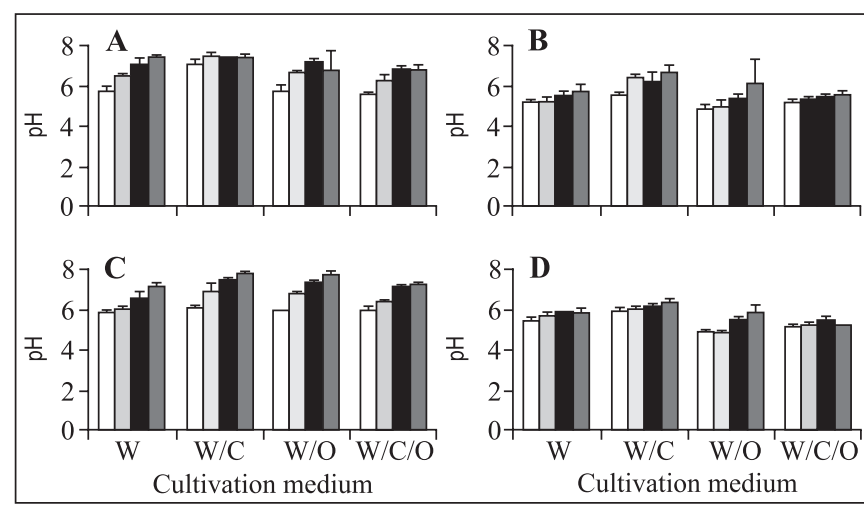

Figure 3. pH values in the cultured medium after solid-state fermentation of Monascus sp N8 and Aspergillus sp N12 strains. A, B = Monascus sp; C, D = Aspergillus sp; A, C = $45^{\circ} \mathrm{C} ; \mathrm{B}, \mathrm{D}=50^{\circ} \mathrm{C}$. SSF was carried out on various substrates, as indicated in figure, and different time intervals. $\square=48 \mathrm{~h}, \square=$ $72 \mathrm{~h}, \boldsymbol{\square}=96 \mathrm{~h}, \square=120 \mathrm{~h}$.

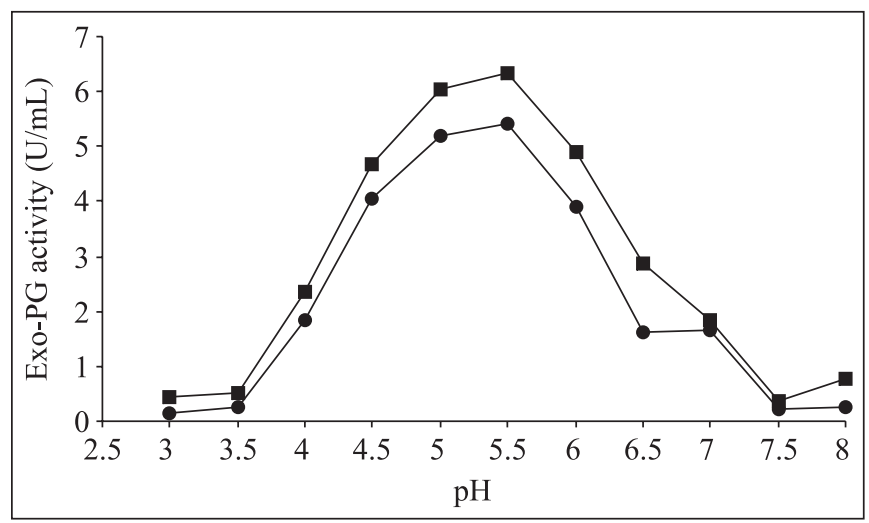

Figure 4. Effect of pH on exo-polygalacturonases activities. $\boldsymbol{0}=$ Exo-Pg from Monascus sp N8, $\mathbf{\square}=$ Exo-Pg from Aspergillus sp N12.

when incubated for one hour in absence of substrate. Pectinases from Aspergillus strains have been described as susceptible to denaturation in temperatures above $50^{\circ} \mathrm{C}(2,4,18)$. Juice enzymatic clarification may be carried out at $15^{\circ} \mathrm{C}$ for $12 \mathrm{~h}$ or at $54^{\circ} \mathrm{C}$ for $1-2 \mathrm{~h}$ for to prevent yeast growth (10). An enzyme that maintaining its stability in these condition is desirable.

\section{CONCLUSIONS}

The present work shows that it is feasible to use agroindustrial wastes for polygalacturonase production by newly isolated thermophilic Monascus sp N8 and thermotolerant Aspergillus sp N12. These fungi are able to produce high levels of polygalacturonases during the solid-state fermentation using

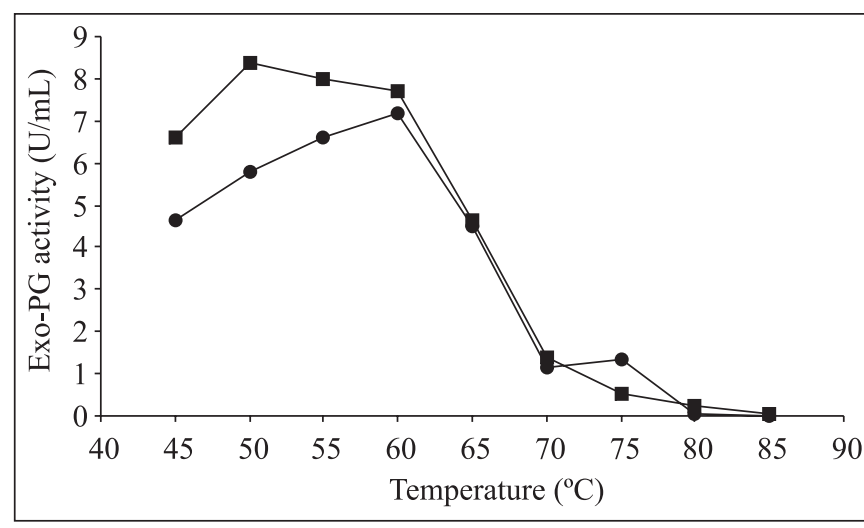

Figure 5. Effect of temperature on the exo-activity of exopolygalacturonases activities. $=$ exo-Pg from Monascus $\mathrm{sp}$ $\mathrm{N} 8, \boldsymbol{\square}=$ exo-Pg from Aspergillus sp N12.

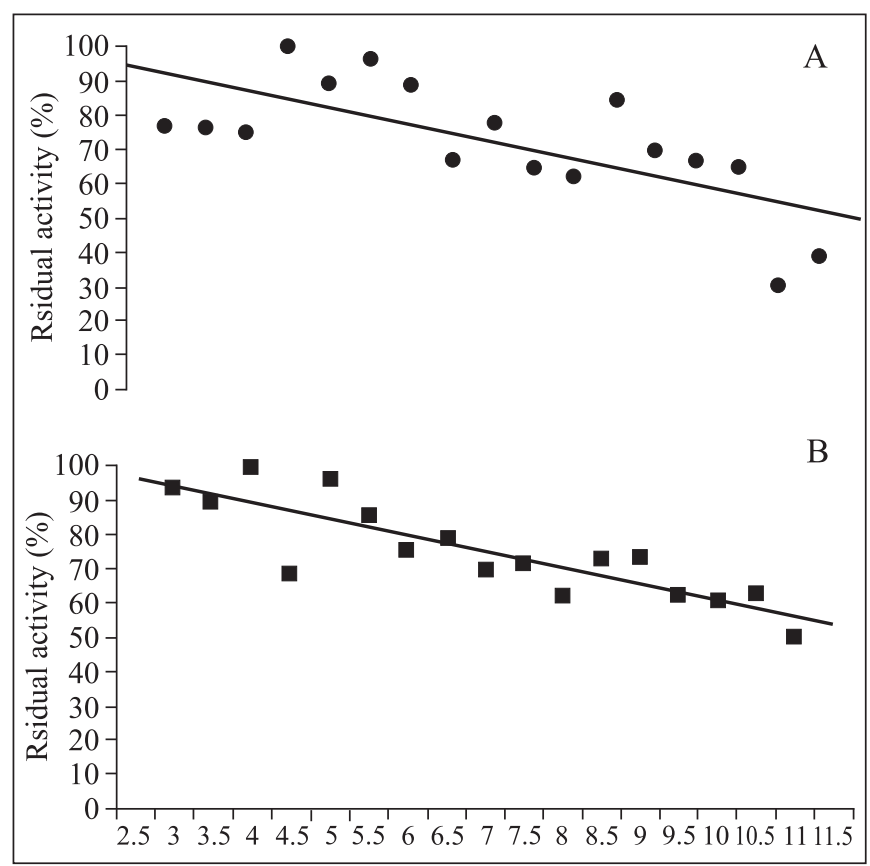

Figure 6. Stability of the exo-polygalacturonases against $\mathrm{pH}$. A = exo-Pg from Monascus sp N8, B = exo-Pg from Aspergillus sp N12.

a mixture of wheat bran, orange bagasse and sugar cane bagasse as substrate.

Polygalacturonases produced by Monascus sp N8 and Aspergillus sp $\mathrm{N} 12$ have a relatively higher optima temperature (60 and $50^{\circ} \mathrm{C}$, respectively), and a low optima $\mathrm{pH}$ (5.5), with good thermal stability $\left(50^{\circ} \mathrm{C}\right.$ for both) and a high tolerance to low $\mathrm{pH}$ (4.5-6.0 and 4.0, respectively). These properties could lead to their becoming acceptable in food industry for fruit juices processing. 


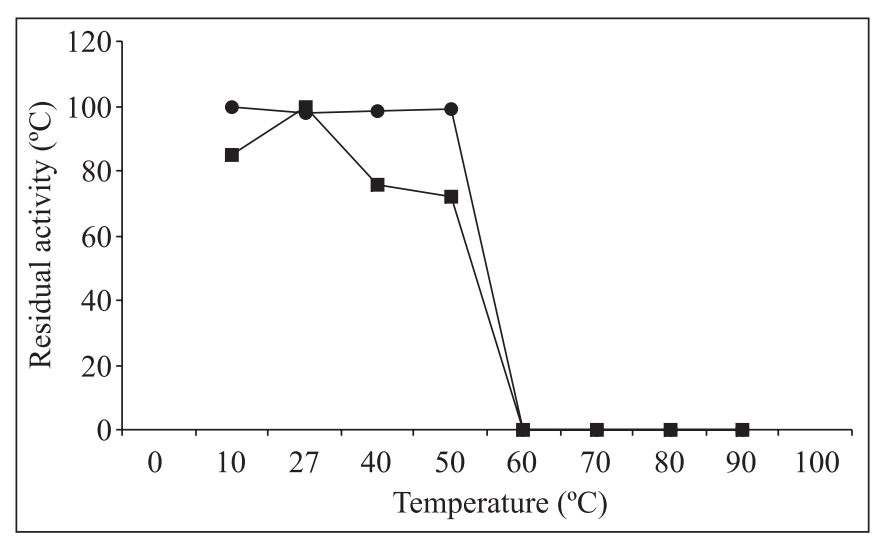

Figure 7. Stability of the exo-polygalacturonases produced by Monascus sp N8 and Aspergillus sp N12 against temperature. - = exo-Pg from Monascus sp N8, $\mathbf{\square}=$ exo-Pg from Aspergillus sp N12.

\section{ACKNOWLEDGEMENTS}

We thank Fundação de Amparo a Pesquisa do Estado de São Paulo- FAPESP- and to Conselho Nacional de Desenvolvimento Científico e Tecnológico-CNPq- for financial support.

\section{RESUMO}

\section{Produção e caracterização parcial de poligalacturonases produzidas pelo fungo termofílico Monascus sp N8 e pelo termotolerante Aspergillus sp N12 em fermentação em estado sólido}

A produção de poligalacturonases pelas linhagens fúngicas recentemente isoladas, Monascus sp N8 e Aspergillus sp N12, foi estudada através de fermentação em estado sólido usando como substratos misturas de farelo de trigo, bagaço da cana-deaçúcar e bagaço de laranja. A atividade máxima de exo-Pg produzida por Monascus $\mathrm{sp}(6,6 \mathrm{U} / \mathrm{mL})$ foi obtida quando o meio de cultivo utilizado continha mistura de farelo de trigo, bagaço da cana-de-açúcar e bagaço de laranja (1:1:1), enquanto que Aspergillus sp produziu maior quantidade da enzima $(10 \mathrm{U} / \mathrm{mL})$ em meio de farelo de trigo e bagaço de laranja. A maior produção de exo-Pg foi obtida através de incubação das culturas a $45^{\circ} \mathrm{C}$ quando comparadas àquelas incubadas a $50^{\circ} \mathrm{C}$. A produção de endo-poligalacturonase (endo-Pg) pelas duas linhagens não foi afetada pela temperatura de incubação. A atividade de endo-Pg em meio de cultura Monascus sp foi $1.8 \mathrm{U} / \mathrm{mL} \mathrm{a} 45^{\circ} \mathrm{C} \mathrm{em} 72 \mathrm{hs} \mathrm{de}$ fermentação e $1,6 \mathrm{U} / \mathrm{mL}$ a $50^{\circ} \mathrm{C}$ em 120 hs de fermentação nas mesmas condições. Valores semelhantes foram obtidos pelo cultivo de Aspergillus sp com $1.9 \mathrm{U} / \mathrm{mL}$ a $45^{\circ} \mathrm{C}$ a $1.8 \mathrm{U} / \mathrm{mL}$ at $50^{\circ} \mathrm{C}$. As exo-poligalacturonases produzidas por ambas as linhagens mostraram maiores atividades em $\mathrm{pH}$ 5,5. Enzimas de
Monascus sp foi mais ativa a $60^{\circ} \mathrm{C}$ e a de Aspergillus sp, a $50^{\circ} \mathrm{C}$. A exo-Pg produzida por Monascus sp foi estável em valores de pH entre 4,5-6,0, enquanto a de Aspergillus sp foi estável somente em $\mathrm{pH} 4,0$. Ambas as enzimas mostraram-se estáveis por 1 hora a $50^{\circ} \mathrm{C}$, quando incubadas em ausência de substrato.

Palavras-chave: Monascus sp, Aspergillus sp, termofílico, poligalacturonase, fermentação em estado sólido

\section{REFERENCES}

1. Antranikian, G. In: Winkelmann, G. (Ed.), Microbial Degradation of Starch in Microbial Degradation of Natural Products. UCH, Weinheim, Germany, 1992, p.27-51.

2. Bailey, M.J.; Pessa, E. Strain and process for production of polygalacturonase. Enz. Microbiol. Technol., 12, 266-71, 1990.

3. Da Silva, R.; Franco, C.M.L.; Gomes, E. Pectinases, hemicelulases e celulases, ação, produção e aplicação no processamento de alimentos: Revisão. Bol. SBCTA, 31(2), 249-260, 1997.

4. Galiotou-Panayotou, M.; Kapantai, M.; Kalantzi, O. Growth conditions of Aspergillus sp ATHUM-3482 for polygalacturonase production. Appl. Microbiol. Biotechnol., 47, 425-9, 1997.

5. Galiatou-Panayotou, M.; Rodis, P.; Kapantai, M. Enhanced polygalacturonase production by Aspergillus niger NRR1-364 grown on supplemented citrus pectin. Lett. Appl. Microbiol., 17, 145-8, 1993.

6. Gummadi, S.N.; Panda, T. Purification and biochemical properties of microbial pectinases - a review. Process Biochem., 38, 987-996, 2003.

7. Guneet, K.; Sanjeev, K.; Satyanarayana, T. Production, characterization and application of a thermostable polygalacturonase of a thermophilic mould Sporotrichum thermophile Apinis. Biores. Technol., 94, 239243, 2004.

8. Hang, Y.D.; Woodnms, E.E. Production of fungal polygalacturonase from apple pomace. Lebensm. Wiss. U. Technol., 27, 194-6, 1994.

9. Ishii, S.; Yokotsuka, T. Pectin trans-eliminase with fruit juice clarifying activity. J. Agric. Food Chem., 19(5), 958-961, 1971.

10. Lea, A.G.H. In: Tucher, G.A.; Woods, L.F.J. (eds.). Enzymes in food processing. Glasgow: Backie Academic and Professional, 1998, p. 223-47.

11. Martins, E.S.; Silva, D.; Da Silva, R.; Gomes, E. Solid-state production of thermostable pectinases from thermophilic Thermoascus aurantiacus. Process Biochem., 37, 949-954, 2002.

12. Miller, G.L. Use of dinitrossalicylic acid reagent for determination of reducing sugars. Anal. Chem., 31, 426-428, 1959.

13. Mitchell, D.A.; Krieger, N.; Stuart, D.M.; Pandey, A. New developments in solid-state fermentation. II. Rotational approaches to the design, operation and scale-up of bioreactors. Process Biochem., 35, 1211-1225, 2000.

14. Mitchell, D.A.; Do, D.D.; Greenfield, P.F.; Doelle, H.W. A semimechanistic mathematical model for growth of Rhizopus oligosporus in a model solid-state fermentation system. Biotechnol. Bioeng., 38, 353-362.1991.

15. Rexova-Benkova, L.; Markovic, O. Pectic enzymes. Adv. Carb. Chem. Biochem., 33, 323-385, 1976.

16. Silva, D.; Martins, E.S.; Silva, R.; Gomes, E. Pectinase production by Penicillium viridicatum RFC3 by solid-state fermentation using agricultural wastes and agro-industrial by-products. Braz. J. Microbiol., 33, 318-324, 2002.

17. Solis-Pereira, S.; Favela Torres, E.; Viniegra-Gonzales, G.; GutierrezRojas, M. Effect of different carbon source on the synthesis of pectinase by Aspergillus niger in submerged and solid-state fermentation. Appl. Microbiol. Biotechnol., 39, 36-41, 1993.

18. Ueda, S.; Yusaku, F.; Lim, J.Y. Production and some properties of pectic enzymes from Aspergillus oryzae A-3. J. Appl. Biochem., 4, 524-32, 1982. 